\title{
A 3000 YEAR OLD DOG BURIAL in Timor-Leste
}

\author{
Antonio Gonzalez ${ }^{1}$, Geoffrey Clark ${ }^{2}$, Sue O'Connor ${ }^{2}$ and Lisa Matisoo-Smith ${ }^{3}$
}

\begin{abstract}
The domestic dog (Canis familiaris) is considered to be the oldest domesticated animal in the world. It arrived in Island Southeast Asia and Australia-New Guinea relatively late in the Holocene, though the timing and means of its dispersal remain unclear. We report a dog burial from Timor-Leste dated to 3000 cal. BP. Morphometric analysis demonstrates strong affinities between this individual and contemporary domestic dog groups, and particularly with the 'village dog' type, indicating it was indeed domesticated, rather than feral-wild. Isotope values which indicate a diet dominated by terrestrial plant foods rather than hunted foods suggest an association between the Timor dog and agriculturalists. Results suggest that the range expansion of $C$. familiaris in the Indo-Pacific is associated with the dispersal of farming groups in prehistory.
\end{abstract}

\section{Introduction}

Two points stand out in a review of the scanty record of early archaeological dog remains in the Indo-Pacific. First, the earliest dates for the dog in mainland Asia and Island Southeast Asia suggest that the animal spread mainly with the expansion of farming groups, although Oskarsson et al. (2011:1400) suggested that 'dogs may have been present in Island Southeast Asia before the arrival of the Neolithic'. Second, the oldest domesticated dog remains already display substantial inter- and intrasite morphological variation, in part from different environmental conditions, but probably more important were the particular relationships between dogs and different prehistoric human societies in the region. A closer association between dogs and people has been argued to be characteristic of the 'village dog' type (Medway 1977) in contrast to the more informal association between people and the 'large pariah' type, and a recent review of skeletal data suggests that the village dog evolved concurrently with the spread of Neolithic farming communities in tropical Asia and Africa (Gonzalez 2012). In this paper, we describe an early dog burial from Timor-Leste dating to $\sim 3000 \mathrm{cal}$. BP, and report ancient DNA, isotopic and morphometric analyses. Results indicate a gracile dog aged three to four years of age that likely belonged to an agricultural community. The dog appears to have been well-cared for during its life, and was possibly used as a hunting aid/watch dog.

\section{Background}

Genetic evidence suggests the domestic dog (Canis familiaris) originated in Southeast Asia, south of the Yangtze River, less than

\footnotetext{
School of Archaeology and Anthropology, College of Arts and Social Sciences, The Australian National University, Canberra ACT 0200, Australia <antonio.gonzalez@anu.edu.au>

2 Archaeology and Natural History, College of Asia and the Pacific, The Australian National University, Canberra ACT 0200, Australia $<$ geoffrey.clark@anu.edu.au><sue.oconnor@anu.edu.au>

${ }^{3}$ Department of Anatomy, University of Otago, PO Box 56, Dunedin, New Zealand <lisa.matisoo-smith@anatomy.otago.ac.nz>
}

16,000 years ago, with numerous archaeological dog remains present in many parts of the world 10,000 years ago, including in north China (Jing 2008; Klütsch and Savolainen 2011; Pang et al. 2009). On archaeological evidence the arrival of the dog south of China appears to be relatively late, with the oldest dog remains dating to 4200-3500 BP in peninsular Southeast Asia, though an earlier introduction is possible from the presence of $\mathrm{dog}$ associated with the Tapenkeng culture in Taiwan 5000-4500 BP (Larson et al. 2012; Tsang 2005). In the Philippines and Batanes, dog is dated to $\sim 2500 \mathrm{BP}$, although a single tooth in a layer from the Uattamdi site on Kayoa Island dating to 3500 BP suggests it may be older in the Moluccas (Bellwood 1998). In New Guinea the dog has an age of 2500-2350 BP (Bulmer 2001; McNiven et al. 2012); however, a recent study of the paternal ancestry of the dingo indicates it is exclusively derived from New Guinea dogs, suggesting that the dog was introduced to Australia-New Guinea 4000-3000 years ago and became wild-feral in Australia and feral-domesticated in New Guinea (Ardalan et al. 2012; Letnic et al. 2012).

The chronology of dog dispersal in Island Southeast Asia and the Pacific has been argued to be congruent with an early phase of Neolithic expansion (Bellwood 1998), but current archaeological data suggests the dog could have arrived on some Pacific islands later in the Neolithic (Addison and MatisooSmith 2010; Anderson 2009). In Island Southeast Asia the timing of the dispersal of dogs, as for other domesticates, has yet to be established by direct dating of dog remains (e.g. O'Connor et al. 2011). Nonetheless, it seems clear that the distribution of the domestic dog and feral/wild forms dramatically expanded as a result of Neolithic population movements in Island Southeast Asia and the west Pacific.

A detailed study of bones recovered from the Ban Chiang site in Thailand, dated to $3200-3000$ BP (Higham et al. 2011), and related excavations, identified two types of dog (Higham et al. 1980). One was a smaller type with an estimated body weight of $8.5 \mathrm{~kg}$ and the other was larger, with a carnassial length within the range of the Australian dingo (18.8-20.6 mm). The estimated body weight of the larger type was $12-20 \mathrm{~kg}$, which suggests a dog similar in size to the dingo-type large pariah; this form is still present in parts of South Asia, Southeast Asia and the Middle East and is recognised by a medium body size, well-proportioned ribcage, relatively long back, long legs and a head with a 'pearshaped' outline when viewed from above (Gonzalez 2012).

The morphology of the Ban Chiang specimens is similar to that of recent South Asia and Southeast Asia pariah populations, which Gonzalez (2012) divided into four types (dingo, sight hound, broad head dog and village dog). Measurements of dog remains from Neolithic levels in Niah Cave in Borneo indicate these animals had a body size smaller than the average village dog (Clutton- Brock 1959; Medway 1959). Further west, in east Java, Storm (2001) examined an incomplete skull from Hoekgrott Cave, which could represent either a large village dog, or a smaller dingo-type pariah; this specimen was tentatively dated to 
$2655 \pm 60$ BP. In Timor, dog remains from Uai Bobo 1 (1400 BP) and Bui Ceri Uato (0-2500 BP) were described by Gollan (1982) as representing two types, one similar to the village dog, and the other larger and more dingo-like.

\section{Matja Kuru 2 Excavation}

In the east of Timor-Leste, adjacent to Lake Ira Laloro ( 334 m asl), are two caves in uplifted limestone known as Matja Kuru 1 (MK1) and Matja Kura 2 (MK2). These are located approximately $9 \mathrm{~km}$ from the current coastline, with entrances facing south over the large freshwater lake (Figure 1). MK2 is one of several sites excavated locally which contain marine resources dating to the Pleistocene (Spriggs et al. 2003). A 1 x $1 \mathrm{~m}$ test pit yielded well-preserved faunal remains throughout the sequence, including abundant remains of giant rats, reptiles and freshwater turtles, from layers dating to $36,000-30,000 \mathrm{cal}$. BP. Evidence for use of the coastal environment includes a broad range of marine shellfish, fish and turtle, which are most abundant in the earliest occupation phase. The earliest date obtained was $\sim 36,000 \mathrm{cal}$. BP on marine shell from Spit 47, though bedrock was not reached during excavation and it is likely that older occupation deposits are present. Dates from higher in the sequence cluster into two periods: $13,000-9500 \mathrm{cal}$. BP and $>3500 \mathrm{cal}$. BP. It thus appears that the deposit accumulated episodically, with an early occupation phase prior to 30,000 years ago, followed by a second occupation phase in the terminal Pleistocene-early Holocene, and a final phase in the mid- to late Holocene. MK2 currently has no evidence for human use between $\sim 30,000 \mathrm{BP}$ and 13,000 BP, the time coinciding with the Last Glacial Maximum (O'Connor and Aplin 2007; Veth et al. 2005).

During excavation a dog skeleton was found in Spits 26-25

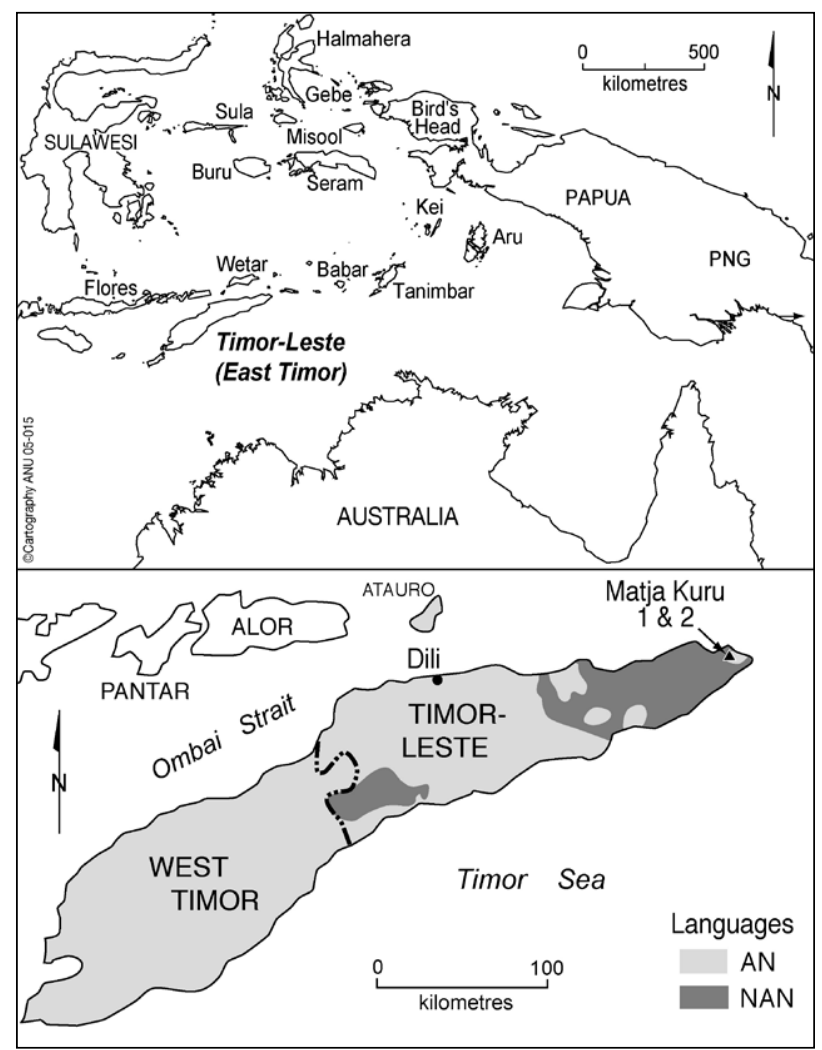

Figure 1 Map of Timor-Leste (East Timor) showing the location of the Matja Kuru 2 (MK2) cave and other archaeological sites of relevance. of MK2, with these remains appearing to have been interred in a pit dug from overlying levels. Pottery was present in small quantities in Spits 19-12, with most ceramics occurring in Spits 11-8. Two pot sherds in Spits 26-25 were found with the dog bone, indicating displacement of pottery from ceramic levels during digging of the burial pit.

\section{AMS and Isotopic Results}

Two samples from the dog bones were prepared at the Waikato Radiocarbon Laboratory, with AMS determinations run at the Rafter Radiocarbon Laboratory on graphite targets processed by the reduction of $\mathrm{CO}_{2}$ with $\mathrm{Zn}$ in a reaction catalysed by iron powder at a temperature of $\sim 575^{\circ} \mathrm{C}$. The first age determination was made on bone (L. humerus distal+midshaft) gelatin in 2003 and gave a conventional radiocarbon age (CRA) of $2967 \pm 58 \mathrm{BP}$ (Wk-10051). However, the C:N ratio was 3.87 (carbon\% 39.4, nitrogen $\% 11.87$ ), indicating potentially poor sample quality. A new sample of ultrafiltered gelatin (L. femur prox+midshaft) was analysed in 2012 and produced a slightly younger CRA of $2867 \pm 26$ BP (Wk-34931). The C:N ratio of 3.34 indicates good bone preservation (cf. Ambrose and Norr 1993:404; van Klinken 1999) and the sample produced an age of 2921-3075 cal. BP (Calib 6.1.0, two sigma, $p=0.95$ ).

${ }^{13} \mathrm{C}$ and/or ${ }^{15} \mathrm{~N}$ isotopic values from bone protein are regularly used as quantitative measures of different dietary protein sources for humans and animals (Allen and Craig 2009; Field et al. 2009; Richards et al. 2009; Valentin et al. 2010). Carbon isotopes are generally considered to have a linear relationship between marine and terrestrial food sources. Stable nitrogen isotopes indicate the trophic level of an organism and have been used to determine the amounts of animal versus plant protein (Schoeninger and DeNiro 1984).

On Nukuoro Atoll, Davidson (1992) dated two dog bones which had ${ }^{13} \mathrm{C}$ values of -15.4 and -12.5 , suggesting a significant marine component in their diets. Two prehistoric dogs from New Zealand with values of ${ }^{13} \mathrm{C}$ values of -17.6 and -17.1 and ${ }^{15} \mathrm{~N}$ values of 11.3 and 14.3 also consumed some marine foods (Leach et al. 2001:50). In contrast, Santa Rosa Island dogs of the late Holocene Chumash people, who relied exclusively on hunting and gathering wild foods (Rick et al. 2011), subsisted almost entirely on marine resources $\left({ }^{13} \mathrm{C}\right.$ mean $-1.5 \pm 0.8 \%$ and ${ }^{15} \mathrm{~N}$ mean $17.9 \pm 0.5 \%$ ).

The Timor dog has a ${ }^{13} \mathrm{C}$ value of -19.47 and a ${ }^{15} \mathrm{~N}$ value of 9.70 (Wk-34931), which suggests a terrestrial diet similar to that of Pacific pigs, but having less marine food compared to some dogs from the Cook Islands and Marquesas, which also appear to show a difference in the trophic level of marine foods consumed (Figure 2).

\section{Ancient DNA Extraction}

Several attempts were made to extract aDNA from the Timor dog remains. Both teeth (incisor, $\mathrm{M}^{1}$ ) and bone samples (rib fragment) were processed but, while in relatively good condition macroscopically, none were well-preserved with respect to aDNA. After multiple attempts using the bone and tooth samples we amplified a very small fragment of the mitochondrial d-loop, spanning approximately 84 base pairs from site 15536-15628 (based on complete mtDNA genome reported in Bjornerfeldt et al. 2006). Over this very short region the Timor dog sequence 


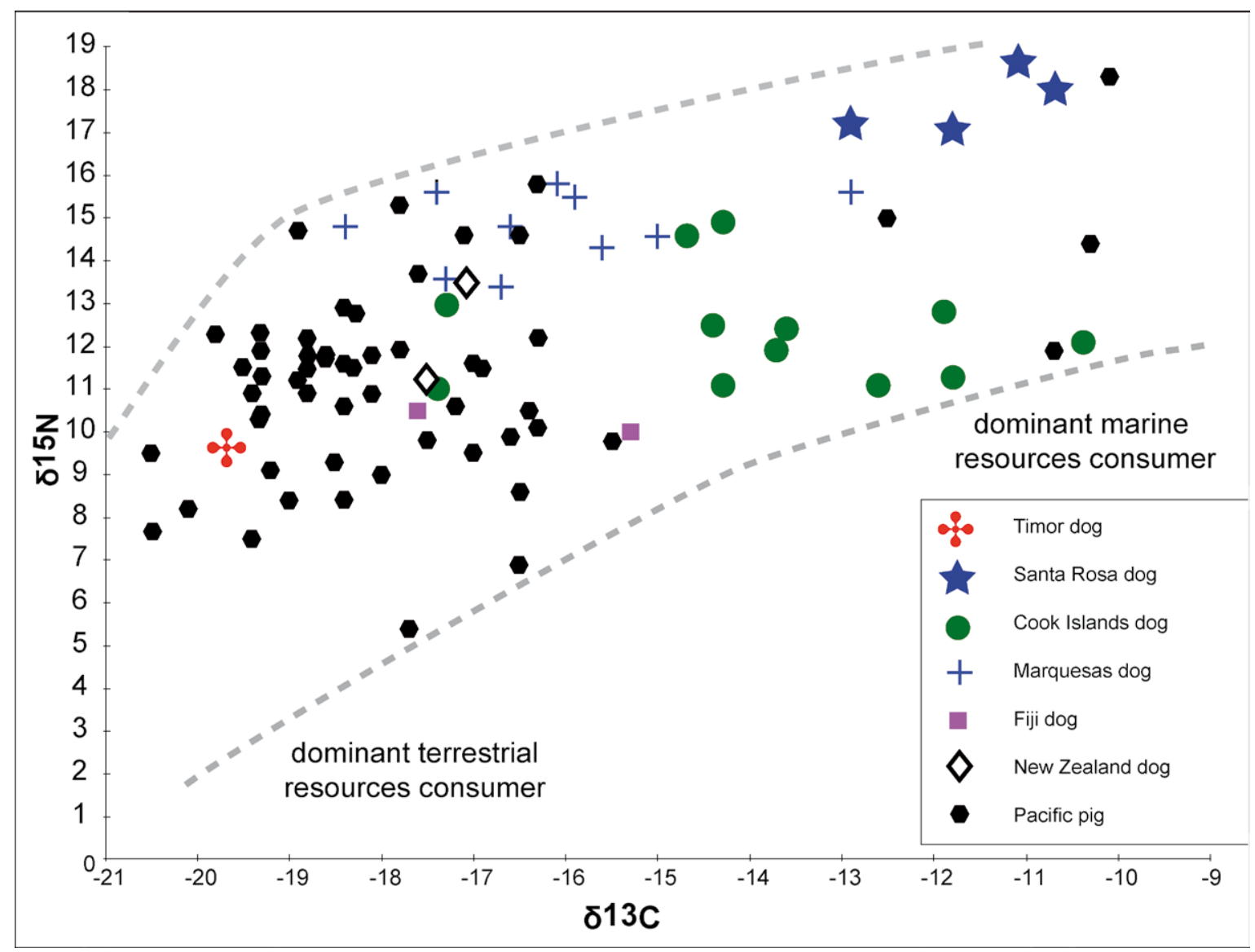

Figure 2 Comparison of Timor dog $\delta^{13} \mathrm{C}$ and/or $\delta^{15} \mathrm{~N}$ isotopic values with those of prehistoric dogs in the Cook Islands (Craig 2009), Marquesas (West 2007), New Zealand (Leach et al. 2001) and Fiji (Jones and Quinn 2009; Valentin et al. 2006). Isotopic values from Santa Rosa dogs are from Rick et al. (2011). Pacific pig isotopic values are derived from Allen and Craig (2009), Beavan-Athfield et al. (2008), Field et al. (2009) and West (2007).

is identical to those of Asian and Asian-derived breeds. Further analyses will focus on the 100 base pairs following site 15628 to determine whether the Timor dog has the point mutations found in dingoes and New Guinea singing dogs (Savolainen et al. 2004).

\section{Osteological Description}

The dog burial comprised 125 bone fragments, representing 92 skeletal elements. The bone was well preserved with little sign of weathering, staining, trampling, burning or gnawing. There is a high incidence of incipient breakage lines that have not developed into cracks; these likely represent the combined effects of the weight of sedimentary overburden and natural decay. The most commonly observed taphonomic feature was recent bone fragmentation which probably occurred post-excavation during transport of the MK2 assemblage to Australia. No cut marks, indicating removal of meat or skinning, were observed on any bones, and the element representation is consistent with the deliberate burial of a complete dog.

Age and physical condition of the dog were evaluated using data related to epiphysial fusion, tooth eruption, pulp cavity size and limb bone thickness. The pulp cavity of the canine was assessed against previously published criteria (Kershaw et al. 2005; Knowlton and Whittemore 2001), and indicates an individual of three to four years of age. Tooth wear was, however, minimal, with dentition presenting well-defined cusps, perhaps reflecting a non-abrasive diet. The specimen was male, based on the presence of a complete os penis. Muscle attachments on the limb bones and the occipital region were deep and well-developed. A degree of pathological development was detected on some lumbar vertebrae, with slight deformation of the spinous processes. Such anomalies can be caused by early extensive muscular growth or by repetitive pack carrying/pulling. The only other anomaly was a supernumerary nutrient foramen in the left tibia. Cause of death was not evident, and the overall condition of the skeleton suggests a well fed and healthy animal. In summary, the skeletal data indicates that the Timor dog was an adult male that lived for three to four years, in which time the animal did not experience severe nutritional shortages; there is no skeletal evidence for severe trauma or disease.

We have attempted to reconstruct the size and weight of the Timor dog using formulas developed by Anderson et al. (1985), Clark (1997), Hamblin (1984) and Wing (1978), which are based on measurements of length and diameter of limb bones, atlas and mandible. We also examined the degree of teeth crowding, which can help to identify wild from domesticated canids, following Davis and Valla (1978; but see Ovodov et al. 2011). Results suggest the Timor canine was a small to mediumsized dog with a body weight of 8-10 kg and a shoulder height of $39 \mathrm{~cm}$ (Table 1). In comparison with modern breeds, it is similar in height to a basenji, but the low body weight reflects a more gracile animal as suggested by the narrow diameter of limb bone mid-shafts. The value of the dental overlap index is 0.67 , which indicates a slight degree of teeth crowding within the domesticated range. 
Tibia: $(2.92 \times G L$ 131.37)+9.41/10

Humerus: (3.43xGL 122.49)-26.54/10*

$393.0 \mathrm{~mm}$

$394.0 \mathrm{~mm}$

\section{Weight Estimation (kg)}

$0.35 \sqrt{ }$ (femur circumference/1.5), after Anderson et al. (1985)

Log body $W=2.1122$ ( $\log$ mandible $H)+1.2722$, after Hamblin (1984)

Log body $W=2.2574(\log$ mandible $H)+1.1164$, after Wing (1978)

$7.7 \mathrm{~kg}$

$9.4 \mathrm{~kg}$

$10.1 \mathrm{~kg}$

Overlapping Index, after Davis and Valla (1978)

Crown length of LM1/alveolar length from LPM4 to LM1

0.67

Table 1 Timor dog height and weight estimates. Key: GL = greatest length; $\mathrm{W}=$ weight; $\mathrm{H}=$ height; LPM4 = lower 1st premolar; LM1 = lower 1st molar; * ${ }^{*}$ based on humerus $\mathrm{GL}=$ (atlas GL $\left.29.32 \times 4.57\right)-11.5$, after Clark (1997).

\begin{tabular}{|c|c|c|c|c|c|}
\hline Measurement & Number & $\begin{array}{l}\text { Timor Dog } \\
\text { (MK2) }\end{array}$ & $\begin{array}{l}\text { New Britain Dog } \\
\text { (NBD) }\end{array}$ & $\begin{array}{l}\text { Australian } \\
\text { Dingo }\end{array}$ & $\begin{array}{l}\text { New Zealanc } \\
\text { Dog (Kuri) }\end{array}$ \\
\hline Greatest length (radius) & 1 & 119.7 & 121.6 & 178.1 & 114.5 \\
\hline $\begin{array}{l}\text { Greatest breadth of the } \\
\text { proximal end (radius) }\end{array}$ & 2 & 14.6 & 13.1 & 17.6 & 16.1 \\
\hline $\begin{array}{l}\text { Smallest breadth of diaphysis } \\
\text { (radius) }\end{array}$ & 3 & 9.3 & 9.4 & 14.5 & 11.5 \\
\hline Breadth of the glenoid cavity & 4 & 13.4 & 12.5 & 19.0 & 13.8 \\
\hline Length of the glenoid cavity & 5 & 20.0 & 19.2 & 26.0 & 22.7 \\
\hline Greatest length (ulna) & 6 & 139.7 & 143.1 & 207.4 & 134.5 \\
\hline $\begin{array}{l}\text { Smallest depth of the } \\
\text { oleocranon }\end{array}$ & 7 & 16.1 & 16.5 & 22.8 & 17.6 \\
\hline $\begin{array}{l}\text { Depth across the processus } \\
\text { anconaeus }\end{array}$ & 8 & 18.1 & 17.9 & 25.8 & 21.9 \\
\hline $\begin{array}{l}\text { Greatest diameter of the } \\
\text { auditory bulla }\end{array}$ & 9 & 18.8 & 20.4 & 25.8 & 18.6 \\
\hline UPM4 length & 10 & 16.3 & 16.8 & 18.7 & 14.3 \\
\hline UPM4 breadth & 11 & 6.3 & 6.2 & 7.3 & 8.3 \\
\hline UM1 length & 12 & 11.2 & 10.4 & 12.2 & 9.0 \\
\hline UM1 breadth & 13 & 15.1 & 14.1 & 15.3 & 11.7 \\
\hline $\begin{array}{l}\text { Length of the upper molar } \\
\text { row }\end{array}$ & 14 & 16.6 & 16.9 & 18.7 & 16.5 \\
\hline $\begin{array}{l}\text { Height of the mandible } \\
\text { behind LM1 }\end{array}$ & 15 & 20.5 & 19.5 & 22.7 & 22.8 \\
\hline LM1 length & 16 & 17.7 & 17.5 & 20.4 & 17.1 \\
\hline LM1 breadth & 17 & 7.1 & 6.7 & 7.9 & 7.3 \\
\hline LM2 length & 18 & 7.7 & 6.8 & 8.2 & 7.4 \\
\hline LM2 breadth & 19 & 6.0 & 5.6 & 6.7 & 5.7 \\
\hline Length of the lower molar row & 20 & 28.7 & 27.9 & 35.2 & 29.7 \\
\hline $\begin{array}{l}\text { Smallest breadth of diaphysis } \\
\text { (femur) }\end{array}$ & 21 & 10.5 & 10.0 & 13.6 & 11.7 \\
\hline Greatest length (tibia) & 22 & 131.3 & 132.4 & 190.4 & 128.3 \\
\hline $\begin{array}{l}\text { Smallest breadth of the } \\
\text { diaphysis (tibia) }\end{array}$ & 23 & 8.5 & 9.8 & 13.4 & 11.3 \\
\hline $\begin{array}{l}\text { Greatest breadth of the distal } \\
\text { end (tibia) }\end{array}$ & 24 & 17.4 & 16.7 & 23.4 & 18.3 \\
\hline $\begin{array}{l}\text { Length of the acetabulum on } \\
\text { the rim (pelvis) }\end{array}$ & 25 & 16.2 & 16.9 & 20.9 & 18.6 \\
\hline
\end{tabular}

Table 2 Measurements used in the log-based comparison shown in Figure 3. For a detailed description of these measurements see von den Driesch (1976). The total sample includes one specimen per group; all measurements are given in mm. Key: UPM4 = upper 4th premolar; UM1 = upper 1st molar; LM1 = lower 1st molar; LM2 = lower 2nd molar. 


\section{Morphometric Analysis}

All measurements used in the comparative study of the Timor dog follow von den Driesch (1976), with the exception of the alveolar length from LP4 to LM1 which was initially described by Davis and Valla (1978). Measurements were collected by the lead author, except those of the prehistoric dog from New Zealand measured by Clark (1997). Measurements obtained are listed in Table 2. Owing to the scarcity of skeletal material from IndoPacific dogs we had to rely on a relatively low specimen number, particularly the comparison of the Timor dog with other village dogs. However, there is a large amount of published osteometric data available concerning the New Zealand dog (Clark 1997), the Australian dingo (especially cranial remains) and the Indian pariah dog. Admixture of the dingo material was assessed by a comparison of eight cranial measurements designed by Corbett (1995) to identify domestic dog-dingo hybrids and wild/feral domestic dogs from dingo remains.

The Australian dingo cranial sample consists of 28 individuals assessed as being dingo using Corbett's (1995) method. All specimens were recorded in public scientific centers and private collections. The sample includes individuals from different parts of the continent, with roughly equal numbers of males and females (as Gollan [1982] found that $68 \%$ of multivariate variation in dingo crania was due to sexual dimorphism).

The island New Guinea dog sample comprises two individuals collected in the 1960s from villages in West New Britain and now located in the Archaeozoology Laboratory in the Department of Archaeology and Natural History at ANU.

Prehistoric dogs from New Zealand (Clark 1997) were included, with the number of measurements varying from element to element. There were 117 measurements for the length of the molar row and 22 for the greatest diameter of the auditory bulla.

Measurements from 88 crania and 50 mandibles of Indian pariah dogs were collected at public organisations/institutions in India, the USA and the UK by the lead author.

Available data suggest the existence of four basic types of early dog in Southeast Asia and Melanesia: 1) the large pariah; 2) the tengger of eastern Java, which is possibly now extinct; 3) the village dog; and 4) a smaller dog similar in size to a lapdog (Gonzalez 2012). There also exist established wild/feral populations that have developed distinct morphological and behavioral adaptations in response to local conditions, as with the New Guinea highland dog (also known as the singing dog) and the Australian dingo. The status of the tengger remains unclear as it has been described as a bush dweller, but its morphology does not show any particular adaptation to life in the wild, and it has been described as being easily domesticated (Storm 2001). Among the four basic early dog types the most relevant to the Timor dog is the village dog type, commonly found in rural parts of Southeast Asia.

The village dog can be differentiated from other types by its restricted distribution, smaller overall size (in comparison to the large pariah), a statistical analysis of bone measurements and visual assessment of living animals by an experienced observer (Gonzalez 2012). Overall, the village dog type can be described as a small to medium-sized canid with features of both modern and primitive dogs. One of the key cranial markers is that the frontal region of the skull is often rather straight, which is a sign of primitiveness, while the palate is usually broad (as in most domesticated dogs). The combination of skeletal traits often found in wild canids alongside those associated with domesticated dogs is a hallmark of the village dog type and is suggestive of incipient paedomorphism.

The log graph of 22 cranial, mandibular and postcranial measurements shown in Figure 3 demonstrates that the Timor and New Britain dogs are very similar to one another, but are different from more specialised forms like the larger-sized dingo and the shorter-but heavier-New Zealand dog. The dingo has a morphology well-adapted to hunting in open forestscrubland, with long limbs, strong joints and a large auditory bulla. In contrast, the prehistoric New Zealand dog has shorter legs and a stocky body that appears to reflect use of the animal by prehistoric Maori for food (Clark 1997).

A discriminant function analysis of six mandibular variables (Figure 4) was undertaken to examine whether the Timor dog had a wild/feral morphology or was more like semi-domesticated/ domesticated types of dog. The analysis of mandibular variables correctly grouped $88.9 \%$ of individuals to one of the three comparative populations (Indian pariah, Indian wolf, Australian dingo), with the first eigenvalue (2.260) responsible for $74.5 \%$ of group variance and the second eigenvalue (0.774) accounting for $25.5 \%$. Wilk's lambda for both functions was highly significant $(p<0.000)$. The mandibular measurements from the Timor dog and two New Britain dogs were entered as ungrouped cases and were grouped with the Indian pariah rather than the wild/feral canids. It should be noted that populations of pariah dogs in India present a wide degree of variability that includes animals with some skeletal dimensions similar to those of the village dog type. Cranial data from a dog collected by the lead author in Calicut (Kerala, India), and measurements of the Malay dog (Medway 1977), also suggest similarity between contemporary village dogs in South Asia-Southeast Asia and the Timor dog (Table 3).

\section{Conclusion}

The mid- to late Holocene-aged dog from Timor described herein has morphological characteristics similar to those of pariah and village dogs from South Asia, Southeast Asia and parts of the Pacific. The main geographic distribution of these types includes much of the tropics. The origins of the village dog may be explained as an adaptive response of the large pariah dog to a tropical environment (e.g. Windle and Humphreys 1890), and perhaps also to a closer association with sedentary human groups. The scant historical information on humandog relations in this region suggests an animal often used as a hunting aid and watch dog that received shelter and food in exchange (Medway 1977; Erik Meijaard pers. comm.; Titcomb 1969). Some dogs in Timor-Leste today still receive preferential treatment for their hunting ability (Sue O'Connor pers. obs.). It is still unclear whether the initial dispersal of the dog in Island Southeast Asia was by hunter-foragers prior to the arrival of agriculturalists, as potentially indicated by genetic divergence estimates for the arrival of the dingo in Australia 4600-18,000 years ago (Oskarsson et al. 2011), or if range expansion was primarily due to a close association between dogs and farmers in the late Holocene. The diet, health and burial of the dog at the MK2 site suggest a domesticated 


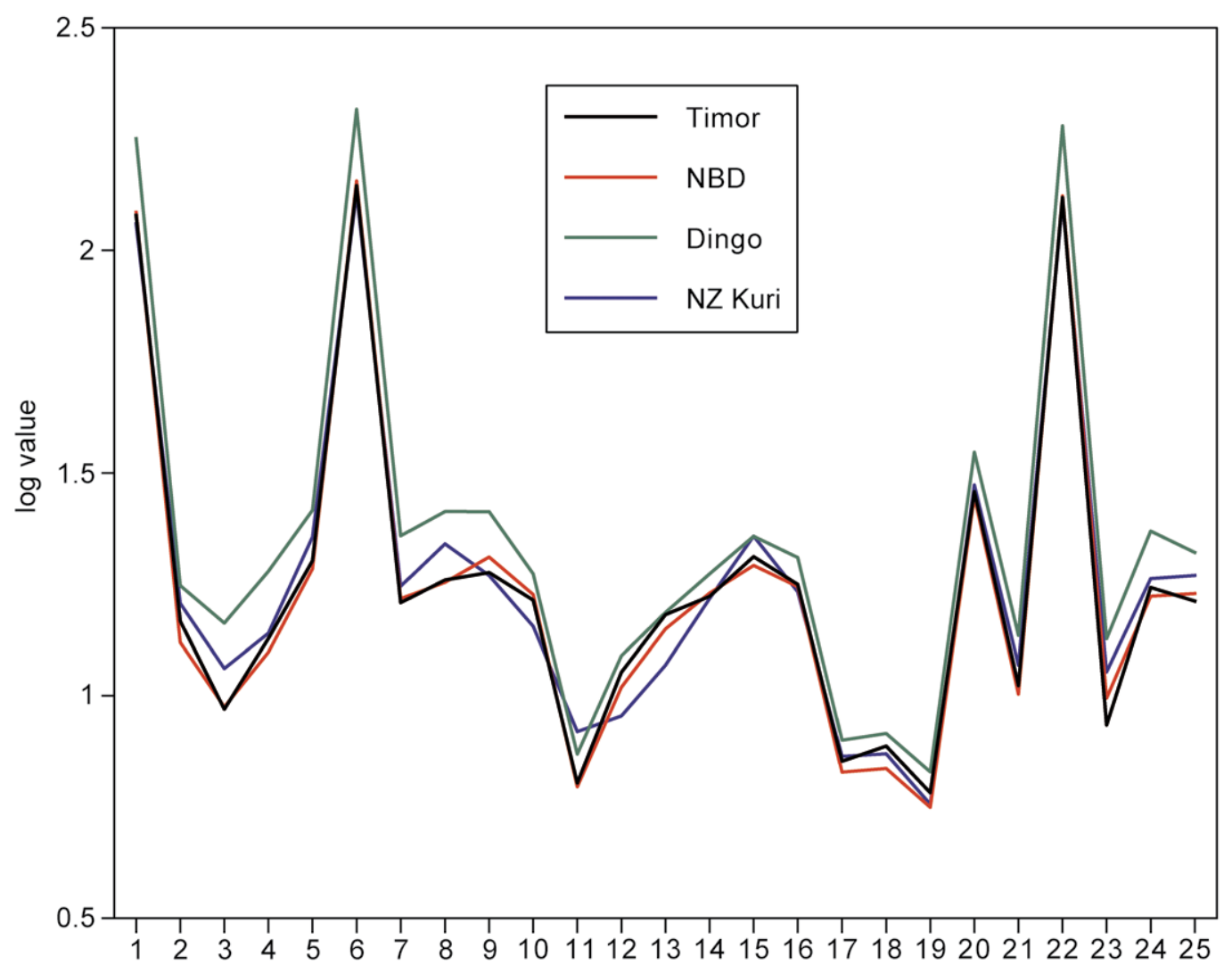

Figure 3 Log graph of 25 cranial, mandibular and postcranial variables from the Timor MK2 dog compared with individuals from New Britain (NBD), Australia (Dingo) and New Zealand (Kuri). See Table 2 for measurements and details of samples.

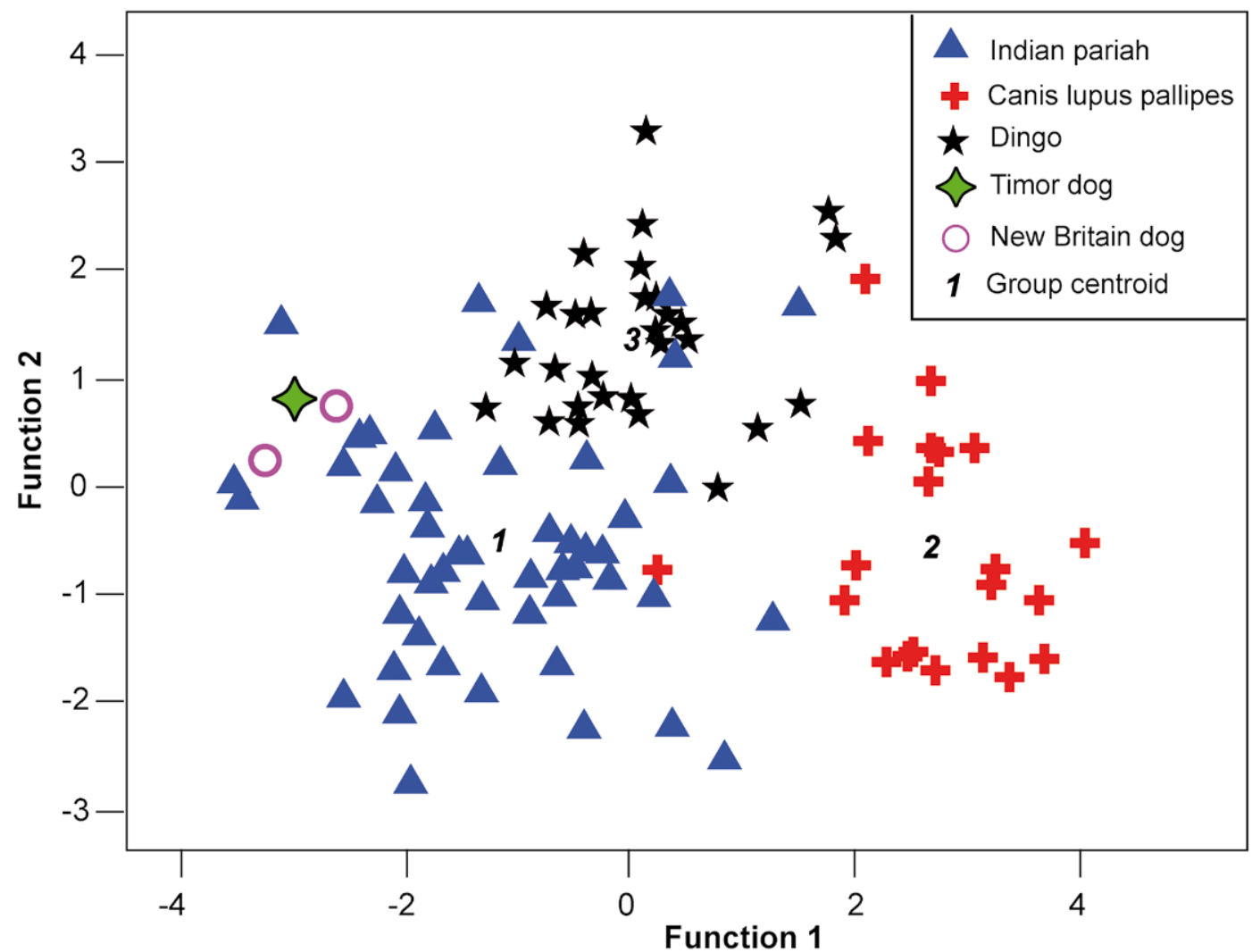

Figure 4 Canonical discriminant function analysis based on six mandibular variables from recent populations of Indian pariah dogs ( 1 , $n=50)$, Indian pale-footed wolves (C. Iupus pallipes) $(2, n=21)$, and Australian dingoes $(3, n=28)$. Ungrouped specimens in the analysis were the Timor dog burial (MK2) and two recent specimens from New Britain, which were grouped with Indian pariah dogs. Mandibular variables used in the DFA were: height of the mandible behind the lower carnassial teeth; height of the mandible at front of the lower carnassial teeth; length of the lower molar row measured along the alveoli; length of the lower carnassial alveolus; LP2-LP3 diastema; and alveolar length from LP4 to LM1. See von den Driesch (1976) for a detailed description of measurements. 


\begin{tabular}{|c|c|c|c|}
\hline Measurement & Timor & Malaya & Calicut \\
\hline UPM4 length & 16.3 & 15.9 & 16.8 \\
\hline UM1-2 length & 16.6 & 15.6 & 17.3 \\
\hline Mandibular height & 20.5 & 19.4 & 20.8 \\
\hline LM1-3 (alv.) length & 28.7 & 28.0 & 29.6 \\
\hline LM1 length & 17.7 & 16.9 & 17.9 \\
\hline Auditory bulla length & 18.8 & 20.0 & 21.6 \\
\hline
\end{tabular}

Table 3 Cranial and mandibular measurements (in $\mathrm{mm}$ ) of the Timor dog and two recent specimens of village dog from Malaya and Calicut (Kerala, India). All measurements are from von den Driesch (1976) except for UM1-2 (length of the upper molar row) (Gonzalez 2012), measured from the anterior edge of the cingulum of the 1st upper molar to the posterior edge of the cingulum of the 2nd upper molar). The Malaya specimen was initially cited as a live specimen by Medway (1977) as 'Manggis' from his private menagerie at Ikan Merah; the complete skull and long bones currently reside at the British Museum (BM 71753) and were measured by Gonzalez in March 2012. The Calicut specimen was collected by Deepak Mathew in nearby farmland and is currently curated in the Gonzalez collection (IN 238) Key: UPM4 = upper 4th premolar; UM1-2 = upper 1st and 2nd molars measured together; LM1-3 (alv.) = alveoli of lower 1st, 2nd and 3rd molars measured together; LM1 = lower 1st molar.

animal that was well-cared for during its life, and which probably had a hunting/watch dog function in a community that practiced agriculture, but also hunted wild/feral species such as cuscus and other fauna with the aid of dogs. Thus, the prehistoric spread of C. familiaris in Island Southeast Asia may attest to the ongoing importance of hunting-foraging in the subsistence of early farming groups, particularly in the new environments encountered during Neolithic dispersal (e.g. Higham 2002).

\section{References}

Addison, D.J. and E. Matisoo-Smith 2010 Rethinking Polynesians origins: A WestPolynesia Triple-I model. Archaeology in Oceania 45:1-12.

Allen, M.S. and J.A. Craig 2009 Dynamics of Polynesian subsistence: Insights from archaeofauna and stable isotope studies, Aitutaki, southern Cook Islands. Pacific Science 63(4):477-506.

Ambrose, S.H. and L. Norr 1993 Experimental evidence for the relationship of the carbon isotope ratios of whole diet and dietary protein to those of bone collagen and carbonate. In J.B. Malbert and G. Grupe (eds), Prehistoric Human Bone: Archaeology at the Molecular Level, pp.1-38. Berlin: Springer-Verlag.

Anderson, A. 2009 The rat and the octopus: Initial human colonisation and the prehistoric introduction of domestic animals to Remote Oceania. Biological Invasions 11:1503-1519.

Anderson, J.F., A. Hall-Martin and D.A. Russell 1985 Long bone circumference and weight in mammals, birds and dinosaurs. Journal of Zoology 207:53-61.

Ardalan, A., M. Oskarsson, C. Natanaelsson, A.N. Wilton, A. Ahmadian and P. Savolainen 2012 Narrow genetic basis for the Australian dingo confirmed through analysis of paternal ancestry. Genetics 140:65-73.

Beavan-Athfield, N., R.C. Green, J. Craig, B. McFadgen and S. Bickler 2008 Influence of marine sources on ${ }^{14} \mathrm{C}$ ages: Isotopic data from Watom Island, Papua New Guinea, inhumations and pig teeth in light of new dietary standards. Journal of the Royal Society of New Zealand 38(1):1-23.

Bellwood, P. 1998 The archaeology of Papuan and Austronesian prehistory in the northern Moluccas, eastern Indonesia. Expansion of East and Southeast Asian Neolithic. In R. Blench and M. Spriggs (eds), Archaeology and Language II: Archaeological Data and Linguistic Hypotheses, pp.128-140. New York: Routledge.

Bjornerfeldt, S., M.T. Webster and C. Vila 2006 Relaxation of selective constraint on dog mitochondrial DNA following domestication. Genome Research 16(8): 990-994.

Bulmer, S. 2001 Lapita dogs and singing dogs and the history of the dog in New Guinea. In G.R. Clark, A. Anderson and T. Vunidilo (eds), The Archaeology of Lapita Dispersal in Oceania, pp.183-201. Terra Australis 17. Pandanus Books: Canberra.

Clark, G. 1997 Osteology of the kuri Maori: The prehistoric dog of New Zealand.
Journal of Archaeological Science 24:113-126.

Clutton-Brock, J. 1959. Niah's Neolithic dog. The Sarawak Museum Journal 9:143145.

Corbett, L. 1995 The Dingo in Australia and Asia. Sydney: University of New South Wales Press.

Craig, J.A. 2009 Stable Isotope Analysis of Prehistoric Human and Commensal Diet on Aitutaki, Southern Cook Islands. Unpublished PhD thesis, Anthropology Department, University of Auckland, Auckland.

Davidson, J. 1992 New evidence about the date of colonisation of Nukuoro Atoll, a Polynesian outlier in the eastern Caroline Islands. Journal of the Polynesian Society 101(3):293-298.

Davis, J.M. and F.R. Valla 1978 Evidence for domestication of the dog 12,000 years ago in the Natufian of Israel. Nature 276:608-610.

Field, J.S., E.E. Cochrane and D.M. Greenlee 2009 Dietary change in Fijian prehistory: Isotopic analyses of human and animal skeletal material. Journal of Archaeological Science 36:1547-1556.

Gollan, K. 1982 Prehistoric Dingo. Unpublished PhD thesis, Research School of Pacific and Asian Studies, The Australian National University, Canberra.

Gonzalez, A. 2012 The Pariah Case: Some Comments on the Origin and Evolution of Primitive Dogs and on the Taxonomy of Related Species. Unpublished PhD thesis, School of Archaeology and Anthropology, College of Arts and Social Science, The Australian National University, Canberra.

Hamblin, N.L. 1984 Animal Use by the Cozumel Maya. Tucson: University of Arizona Press.

Higham, C.F.W. 2002 Early Cultures of Mainland Southeast Asia. Bangkok: River Books.

Higham, C.F.W., A. Kijngam and B.F.J. Manly 1980 An analysis of prehistoric canid remains from Thailand. Journal of Archaeological Science 7:149-165.

Higham, C.F.W., T. Higham and A. Kijngam 2011 Cutting the Gordian Knot. The Bronze Age of Southeast Asia: Origins, timing and impact. Antiquity 85:583598.

Jing, Y. 2008 The origins and development of animal domestication in China. Chinese Archaeology 8:1-7.

Jones, S. and R.L. Quinn 2009 Prehistoric Fijian diet and subsistence: Integration of faunal, ethnographic and stable isotopic evidence from the Lau Island Group. Journal of Archaeological Science 36(12):2742-2754.

Kershaw, K., L. Allen, A. Lisle and K. Withers 2005 Determining the age of adult wild dogs (Canis lupus dingo, C. l. domesticus and their hybrids). I. Pulp cavity: Tooth width ratios. Wildlife Research 32:581-585.

Klütsch, C.F.C. and P. Savolainen 2011 Geographical origin of the domestic dog. Encyclopedia of Life Sciences (eLS). Chichester: John Wiley and Sons. <DOI: 10.1002/9780470015902.a0022867>

Knowlton, F.F. and S.L. Whittemore 2001 Pulp cavity/tooth width ratios from known age and wild caught coyotes determined by radiography. Wildlife Society Bulletin 29(1):239-244. 
Larson, G., E.K. Karlsson, A. Perri, M.T. Webster, S.Y.W. Ho, J. Peters, P.W. Stahl, P.J. Piper, F. Lingaas, M. Fredholm, K.E. Comstock, J.F. Modiano, C. Schellingo, A.I. Agoulnik, P.A. Leegwater, K. Dobney, J-D. Vigne, C. Vilà, L. Andersson and K. Lindblad-Toh 2012 Rethinking dog domestication by integrating genetics, archaeology and biogeography. Proceedings of the National Academy of Sciences of the United States of America. <www.pnas.org/cgi/doi/10.1073/ pnas.1203005109>

Leach, F., C. Quinn, J. Morrison and G. Lyon 2001 The use of multiple isotope signatures in reconstructing human diet from archaeological bone from the Pacific and New Zealand. New Zealand Journal of Archaeology 23:31-98.

Letnic, M., M. Fillios and M.S. Crowther 2012 Could direct killing by larger dingoes have caused the extinction of the thylacine from mainland Australia? PLoS ONE 7(5): e34877.<DOI:10.1371/journal.pone.0034877>

McNiven, I.J., B. David, K. Aplin, J. Mialanes, B. Asmussen, S. Ulm, P. Faulkner, C. Rowe and T. Richards 2012 Terrestrial engagements by terminal Lapita maritime specialists on the southern Papuan coast. In S.J. Haberle and B.David (eds), Peopled Landscapes: Archaeological and Biogeographic Approaches to Landscapes, pp.121-156. Terra Australis 34. Canberra: ANU E Press.

Medway, L. 1959 Niah animal bone: II (1954-58). Sarawak Museum Journal 9(1314):151-163.

Medway, L. 1977 The ancient domestic dogs of Malaysia. Journal of the Malaysian Branch of the Royal Asiatic Society 1(2):14-27.

O'Connor, S. and K. Aplin 2007 A matter of balance: An overview of Pleistocene occupation history and the impact of the Last Glacial Phase in East Timor and the Aru Islands, eastern Indonesia. Archaeology in Oceania 42:82-90.

O'Connor, S., A. Barham, K. Aplin, K. Dobney, A. Fairbairn and M. Richards 2011 The power of paradigms: Examining the evidential basis from early to mid-Holocene pigs and pottery in Melanesia. Journal of Pacific Archaeology 2(2): $1-25$.

Oskarsson, M.C.R., C.F.C. Klütsch, U. Boonyaprakob, A. Wilton, Y. Tanabe and P. Savolainen 2011 Mitochondrial DNA data indicate an introduction through mainland Southeast Asia for Australian dingoes and Polynesian domestic dogs. Proceedings of the Royal Society B: Biological Sciences 279(1730):967-974.

Ovodov, N.D., S.J. Corckford, Y.V. Kuzmin, T.F.G. Higham, W.L. Hodgins and J. van der Plicht 2011 A 33,000-year-old incipient dog from the Altai Mountains of Siberia: Evidence of the earliest domestication disrupted by the Last Glacial Maximum. PLoS ONE 6(7): e22821. <DOI:10.1371/journal.pone.0022821>

Pang, J.F., C. Kluetsch and X.J. Zou 2009 MtDNA data indicate a single origin for dogs south of Yangtze River, less than 16,300 years ago, from numerous wolves. Molecular Biology and Evolution 26(12):2849-2864.

Richards, M.P., E. West, B. Rolett and K. Dobney 2009 Isotopic analysis of human and animal diets from Hanamiai archaeological site (French Polynesia). Archaeology in Oceania 44:29-37.

Rick, T.C., B.J. Culleton, C.B. Smith, J.R. Johnson and D.J. Kennett 2011 Stable isotope analysis of dog, fox and human diets at a late Holocene Chumash village (CA-SRI-2) on Santa Rosa Island, California. Journal of Archaeological Science 38:1385-1393.
Savolainen, P., T. Leitner, A.N. Wilton, E. Matisoo-Smith and J. Lundeberg 2004 A detailed picture of the origin of the Australian dingo, obtained from the study of mitochondrial DNA. Proceedings of the National Academy of Sciences of the United States of America 101(33):12387-12390.

Schoeninger, M. and M. DeNiro 1984 Nitrogen and carbon isotopic composition of bone collagen from marine and terrestrial animals. Geochemica et Cosmochemica Acta 48:625-639.

Spriggs, M., S. O'Connor and P. Veth 2003 Vestiges of early pre-agricultural economy in the landscape of East Timor: Recent research. In A. Kallen and A. Karlstrom (eds), Fishbones and Glittering Emblems: Proceedings from the EurASEEA Sigtuna Conference, pp.49-58. Stockholm: Museum of Far Eastern Antiquities.

Storm, P. 2001 Resten van een hond uit de vindplaats Hoekgrot (Java). Cranium 18(1):31-44.

Titcomb, M. 1969 Dog and Man in the Ancient Pacific. Bernice P. Bishop Museum Special Publication 59. Honolulu: Bernice P. Bishop Museum.

Tsang, C-H. 2005 Recent discoveries at a Tapenkeng culture site in Taiwan: Implications for the problem of Austronesian origins. In L. Sagart, R. Blench and A. Sanchez-Mazas (eds), The Peopling of East Asia, pp.63-73. London: Routledge Curzon.

Valentin, F., H. Bocherens, B. Gratuze and C. Sand 2006 Dietary patterns during the late prehistoric/historic period in Cikobia island (Fiji): Insights from stable isotopes and dental pathologies. Journal of Archaeological Science 33(10):1396-1410.

Valentin, F., H.R. Buckley, E. Herrscher, R. Kinaston, S. Bedford, M. Spriggs, S. Hawkins and K. Neal 2010 Lapita subsistence strategies and food consumption patterns in the community of Teouma (Efate, Vanuatu). Journal of Archaeological Science 37(8):1820-1829.

van Klinken, G.J. 1999 Bone collagen quality indicators for paleodietary and radiocarbon measurement. Journal of Archaeological Science 26:687-695.

Veth, P., M. Spriggs and S. O'Connor 2005 Continuity in tropical cave use: Examples from East Timor and the Aru Islands, Maluku. Asian Perspectives 44:180-192. von den Driesch, A. 1976 A Guide to the Measurement of Animal Bones from Archaeological Sites. Peabody Museum Bulletin 1. Cambridge, MA: Peabody Museum.

West, E.W. 2007 An Archaeological Investigation of Pig Husbandry on Tahuata Island, Marquesas, French Polynesia. Unpublished PhD thesis, Department of Anthropology, University of Hawai' i, Honolulu.

Windle, B.C.A. and J. Humphreys 1890 On some cranial and dental characteristics of the domestic dog. Proceedings of the Zoological Society (London) 12:5-29.

Wing, E.S. 1978 Use of dogs for food: An adaptation to the coastal environment. In B.L.Stark and B.Voorhies (eds), Prehistoric Coastal Adaptations: The Economy and Ecology of Maritime Middle America, pp.29-41. New York: Academic Press. 